\title{
Journey of Theophanes: Travel, Business, and Daily Life in the Roman East
}

James G. Keenan

Loyola University Chicago, jkeenan@luc.edu

Follow this and additional works at: https://ecommons.luc.edu/classicalstudies_facpubs

Part of the Classics Commons

\section{Recommended Citation}

Keenan, JG. Review of Journey of Theophanes: Travel, Business, and Daily Life in the Roman East by John Matthews. Bulletin of the American Society of Papyrologists 43, 2006.

This Book Review is brought to you for free and open access by the Faculty Publications and Other Works by Department at Loyola eCommons. It has been accepted for inclusion in Classical Studies: Faculty Publications and Other Works by an authorized administrator of Loyola eCommons. For more information, please contact ecommons@luc.edu.

\section{(c) (1) $\odot \Theta$}

This work is licensed under a Creative Commons Attribution-Noncommercial-No Derivative Works 3.0 License.

(c) American Society of Papyrologists, 2006. 
John Matthews, The Journey of Theophanes: Travel, Business, and Daily Life in the Roman East. New Haven and London: Yale University Press, 2006. xvii + 244 pages. ISBN 0-300-10898-2.

In 1906 H. Bresslau published in APF 3 (pp. 168-172) a Strasbourg papyrus containing a letter of recommendation in Latin (now CPL 262) in favor of one Theophanes, a scholastikos from the city of Hermopolis in the Thebaid. Years later this letter found a much damaged twin in a papyrus housed in the John Rylands Library, Manchester, providing the essential link in what is now referred to as "the Theophanes archive." The Rylands papyrus, P.Ryl. 4.623 (now CPL 263), was published in 1952 along with 34 other documents that make up the archive's major portion (P.Ryl. 4.616-651; perhaps add 607). A second, smaller portion, five letters belonging to the Egypt Exploration Society, was published in 1964 (P.Herm.Rees 2-6). A succinct register of the archive's documents, including one more letter found among the EES papyri, is set out in the present book, pp. xv-xvi. A detailed publication history of the archive, or archives, including references to stray pieces from what may be called Theophanes' dossier, is given by H. Cadell, "Les archives de Théophanès d'Hermoupolis: documents pour l'histoire," in L. Criscuolo and G. Geraci (eds.), Egitto e storia antica dallellenismo all'età araba (Bologna 1989) 315-323.

The book under review simply begged to be written; for despite its inherent interest, notice of Theophanes' early fourth-century archive, "one of the richest ... of the period" (R. S. Bagnall, Egypt in Late Antiquity [Princeton 1993] 271), has been sporadic and limited to article-length treatments, some of which are difficult to obtain. As the author (M.) points out, the archive is ignored in the standard works on Antioch. Nor, I might add, was its Rylands portion, though available and relevant, used in A.H.M. Jones's Later Roman Empire (Oxford 1964), a work that strikes its readers as having exploited just about every likely primary source.

For those unfamiliar with Theophanes, the basics are that in his capacity as a scholastikos he served in the early 320s on the staff of Egypt's chief financial

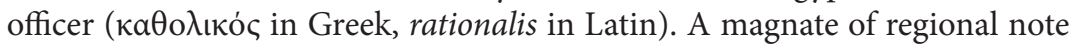
(see the fragmentary domestic accounts, P.Ryl. 4.640-651), in the 'teens he had served as a strategos-exactor. The chief interest of his papers lies in their record of his journey, on an unspecified mission, from Hermopolis (or Antinoopolis) to Antioch. This he, with traveling attendants, free and servile, undertook in 322 or 323 (Bagnall, Egypt in Late Antiquity 271, n. 76), presumably "enjoying the privileges of the public post" (L. Casson, Travel in the Ancient World [new edition, Baltimore and London 1994] 190). Significantly, the documents 
related to the journey include no entries for lodgings, whether on the road or in Antioch, or for the hire of animals, whether as mounts or for carrying supplies on the land leg of the journey out and back. More important, much of the journey lay along an imperially defined route (see M., pp. 62-77, esp. 68-70 on the Bordeaux pilgrim's itinerary; pp. 128-129 on the Antonine itinerary; cf. Roberts' chart, P.Ryl. 4, p. 107, with explanation, pp. 105-106). Treating Allage on Theophanes' route (P.Ryl. 4.627.242, 243; 628.17, 18; and 630*.385) not as a Syrian place-name, but as à $\lambda \lambda \alpha \gamma \eta \dot{\eta}$, a translation of the Latin mutatio (p. 199, a neat insight, cf. P.Ryl. $4.638 .17 \mathrm{n}$.), is a detail that helps clinch this point.

Though his book also has much to interest the papyrologist, M.s primary aim is to provide the Theophanes material, and particularly the evidence for the journey to Antioch, with a comprehensive, accessible treatment for the general reader. Part of this involves placing the archive within the late imperial environment through a liberal use of black-and-white illustrations. Some of these will be familiar to specialists, but not to the general public. For example, figs. 2.5-7 reproduce images of three letters from the plates of P.Herm.Rees; M.s are necessarily smaller, but they are also somewhat darker. Other figures, from the Napoleonic Description de l'Égypte (figs. 2.2-4 and 3.1-2), include well-known plates for Hermopolis and Antinoopolis. Most successful in terms of the joining of illustration and text is the use of drawings from the topographical border of the Megalopsychia Mosaic (figs. 4.6-17, pp. 82-88; cf. text, pp. 77-82; and see p. 79, approving the use of imagination in historical reconstruction). In this undertaking, M. presents, in sequential panels with concise descriptions, the buildings and street scenes Theophanes likely witnessed as he approached, entered, and moved about in Antioch.

Following an introductory first chapter, Chapter 2 ("Hermopolis: Theophanes and His Friends") presents translations of Theophanes' letters. It sets the Egyptian background, physically and socially. Later chapters (3, "The Road to Antioch," 5, "At Antioch," 6, "Homeward Bound" - Chapter 4 is an interlude on travel with sections on the cursus publicus, the Peutinger map, and the city of Antioch) include exact translations of the Rylands memoranda, or accounts, and itineraries. These, the book's core, are presented by design at intervals rather than continuously in one place. As befits the goal of accessibility (see p. viii for M.s explanation), the translations come without Greek texts. Consequently, the papyrus illustrations, those mentioned in the preceding paragraph, but even more so the two figures selected for the Rylands accounts (5.1, 6.1 ), have "magical" rather than "meaningful value," and this at some remove. ${ }^{1}$

${ }^{1}$ Philip Larkin, Required Writing: Miscellaneous Pieces 1955-1982 (London and Boston 1983) 99-100. "Magical" refers to the frisson, or thrill, one gets simply from seeing at first hand autograph writing on a manuscript. 
Nevertheless, Appendix 2, though it does not offer a full commentary, does provide significant "Notes on the Text" (sic), with some Greek lemmata and corrected readings based on autopsy of the originals. Most significant is the restoration of five missed lines to P.Ryl. 4.629 (lines 49a-e); see pp. 192-193. Also important are the changes to P.Ryl. $4.630^{\star}$ on p. 201, where problematic

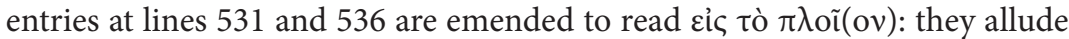
to the journey's return leg by water from Babylon to Hermopolis. Outside of Appendix 2, note the clever if queried substitution (in English), pp. 128-129 and 132, of "Skenae" for "Kenae" as a toponym in P.Ryl. 4.630*.516.

For a historian of such distinction to have fixed upon a papyrological source is surely a welcome event. In the endeavor M. makes a good case for using Theophanes' papers to study history below the level of high politics and a refreshing argument for the value of papypological documentation in general; but this leads to the disconcerting claim (p. 8) that " $[\mathrm{t}]$ o know the conditions of travel from Hermopolis to Antioch and the time it took to get there is to know something just as important to the Roman empire as the change of religion that was lurking around the corner at just the time Theophanes made his journey between those two places." Well, maybe - but aren't the two comparata really non comparanda? At the same time, the Theophanes evidence, especially its travel-related documents, is notable, as M. remarks early on (p. 7), for its bearing on matters outside Egypt. "In fact, this part of the archive turns the question of typicality on its head, for it provides information for places beyond Egypt, on a scale and level of detail that are normally only to be found within it." It is not after all the usual Egyptocentric papyological material dubious amongst historians because of Egypt's presumed Sonderstellung.

In any case, Theophanes' journey, as traced in the documents, lasted six months, including two and a half spent in Antioch. In setting the columns of the accounts in proper sequence, M. concludes (pp. 41-47) that some columns of $P . R y l$. 4.627, columns usually treated as a packing list or preparatory inventory, had nothing to do with the trip itself; rather, they were "household inventories." In treating the outward and return journeys, M. presents an essentially flat topography with only occasional nods to particular challenges like the Nile flood's altering the return route (p. 123) and the demands of barren and desert stretches of road (pp. 127, 128). Expenditures both en route and in Antioch were mostly and not surprisingly for food. Bath-related expenses and those for general entertainment were a distant second, payments for papyrus (see pp. 89, 94, 116, 161, and 193) a still more distant third. (I leave aside the extraordinary payment to a "speedwriter" [oxygraphos] on the last full day in Antioch, p. 162.) In this respect, that is, in their proportions, Theophanes' expenditures invite comparison with those recorded in the recently published 
P.Tebt. 5 = Pap.Lugd.Bat. 32 (reviewed above, pp. 000), detailing expenses in Ptolemaic Kerkeosiris for outside officials present in the village for the annual "survey according to crops." M.'s conclusion (pp. 92 and 171-174) that Theophanes' party used the previous leavings from dinner as a quick breakfast, with ariston, usually translated as "breakfast," indicating lunch, suggests the same may be true of ariston in the Kerkeosiris accounts.

In the last two chapters, I note that Chapter 7 ("Costs and Prices") begins (pp. 138-143) with calculations on price increases between Diocletian's famous edict of 301 and the time of Theophanes' travels, concluding that prices were five times higher in 321 than in 301; the annual inflation rate was about $8 \%$. The point here is to argue that Diocletian's edict was not the failure that his ancient critics and most modern scholars have maintained. The rest of this chapter routinely summarizes Theophanes' expenses. (See also Appendix 3.) The discussion of "Food and Diet" in Chapter 8 ends with consideration of some of Theophanes' lunch and dinner menus and a narrative reading of the "Mosaic of the Buffet Supper," a remarkable ancient still life.

The book offers no general conclusions, but ends with a set of appendices. The first summarizes the contents of P.Ryl. 4.627. The second contains the above-mentioned notes on the documents. Appendix 3 valuably arranges Theophanes' expenditures item by item. Appendix 4 tries to resolve the meanings of kemia and kemoraphanos. Both, which appear frequently in the accounts, are to be associated with vegetables.

In all, M. well achieves his aim - though the inclusion of "Business" in the book's sub-title is puzzling. I also canot help believing that The Journey of Theophanes includes much that the general reader will skim. The papyrologist, on the contrary, will want to read closely with P.Herm.Rees and P.Ryl. 4 conveniently at hand. The book's typography is virtually flawless but there are some minor errors as well as inconsistencies in detail that seem attributable to a want of editorial integration of the book's different components. On p. 10 the point that papyrologists have greater reason to publish unpublished material than to revise existing editions in full scale is right, but the figures taken to show how much virgin material remains (footnote 22, in a confusing use of N. Lewis, Life in Egypt under Roman Rule [Oxford 1983] 6) are way short. A reliable source for the holdings of the Egypt Exploration Society alone puts the total at half a million. Throw in what is unpublished in Berlin and Vienna and we start credibly moving toward the million mark. This simply makes M.'s point all the stronger. On pp. 29 and 30 for agapitos, agapetos should be read (see fig. 2.7, line 1). The place-name labels on the maps, pp. 57-58, are too often, and without explanation, at odds with the names as they are given in the texts of the itineraries presented at the end of Chapter 3, most strikingly in the case of 
Gabala (Map 2, p. 58; text p. 61) vs. Ibella (text, p. 59 bis). See p. 127, n. 11, for clarification, but also for further confusion in that note's reference to "Iamneia," which appears as "Iamnia" on the p. 58 map and as both "Iamnia" and "Jamnia" (bis) on p. 59. On p. 70 Antinoopolis seems to be treated as a mere re-naming of the city by Hadrian, not as a new foundation. The description of fig. 4.14, p. 86, refers to "Leontios," but the description of fig. 4.15, p. 87, refers to "Leontius's establishment." The description of fig. 4.17 , p. 88 , should probably note that "Ardabourios" is a Germanic name. The approaching man in the middle of that figure holds the basket in his right - left facing the reader - not his left hand. On p. 134, the translation for the item entered in P.Ryl. $4.630^{*} .374$ is "[??ba] th," but the note ad loc. in Appendix 2, p. 199, does not supply the necessary restoration, ? $\beta a]$ ] $a v i$ iov. On p. 181, the presence of officiales need not point to agents of the central government - they could have been provincial. Likewise, the name Hermes appears a dozen times in the Rylands accounts, but only once (P.Ryl. 4.627.99) is its owner earmarked as a messenger, dromeus. If he was a slave (p. 95; cf. p. 164), the name does seem a tasteless joke; but if dromeus is simply a translation of the Latin cursor (p. 95, n. 15), it is possible that this Hermes, who need not be identical with Theophanes' domestic phrontistes, was a sub-clerical provincial staff officer assigned to assist Theophanes.

Finally, it bears mention that another Egyptian, Flavius Isidorus, officialis on the gubernatorial staff of the Thebaid, made a journey from Hermopolis to Syrian Hierapolis a half century after Theophanes' journey to Antioch (P.Lips. 1.34-35). Since he doubtless traveled some of the same route, it is a pity that his records have not survived for purposes of comparison. 